\title{
RUSSIAN LANGUAGE ABROAD: VIEWING LANGUAGE THROUGH THE LENS OF COMMODIFICATION
}

\author{
Sebastian Muth \\ Institute of Multilingualism, University of Fribourg \\ 24 Rue de Morat, CH 1700 Fribourg, Switzerland

\section{РУССКИЙ ЯЗЫК ЗА РУБЕЖОМ: ВЗГЛЯД НА ЯЗЫК СКВОЗЬ ПРИЗМУ КОММОДИФИКАЦИИ}

\author{
Себастьян Мут \\ Институт многоязычия, Университет Фрибурга \\ 24 Rue de Morat, CH 1700 Fribourg, Switzerland
}

After a successful 2-volume issue on discourse analysis (Ponton, Larina 2016, 2017) we are happy to offer the readers of Russian Journal of Linguistics another special issue this time dedicated to a new sociolinguistic topic - commodification of language. We will discuss what language commodification is, focus on its antecedents and methods of study and consider commodification of the Russian language in different countries Lithuania, India, China, Israel, Spain, Norway, Finland and Bulgaria. All the contributions document the historical moment when Russian became one of the most popular languages in the international service industry within the framework of transnational leisure- and shopping tourism. Furthermore, the contributions to this special issue underscore how geopolitical, economic, social, and demographic factors influence processes of commodification and decomodification of the language. Viewed from the economic perspective, these essays draw attention to motivations behind attempts to turn Russian into a 'valuable' communicative resource. Finally, the papers explicitly or implicitly investigate the role of teaching and learning Russian as part of the language commodification, revealing how state and corporate policies promote the learning of Russian and boost individual motivation to acquire proficiency in Russian in order to meet market-driven demand that calls for the linguistic accommodation of Russian-speaking tourists.

\section{WHAT IS LANGUAGE COMMODIFICATION AND WHY IS IT IMPORTANT FOR LINGUISTS TO STUDY?}

Indeed, why is it important for us as linguists to study the commodification of languages and speakers? Why do we find it fruitful to highlight the changing role of language under current socio-economic conditions that are characterized by an increasing exchange of goods, services and labor? Are we witnessing an onset of the global neoliberal economy 
which allows for the commodification of virtually anything, including language? And lastly, what tensions may this re-imagination of language create and what are the consequences of this realignment? These questions are at the heart of the special issue "Commodification of Russian" and to address them we have to consider the role of language in society and how this role evolved from realities of nation states turning language into a communicative resource. The underlying assumption first put forward by the Canadian sociolinguist Monica Heller (2003) and the Swiss sociolinguist Alexandre Duchêne (2009) has it that when strategically employed through marketing or the availability of suitable speakers, languages (and speakers) may provide for an added value to a product or service.

To illustrate this, let us take a look at ethnographic research I conducted in Lithuania, a former Soviet Republic that in recent years became a popular medical-tourism destination for Russian speakers from Belarus, the Kaliningrad region and Western Russia (Muth 2017a). To put this movement of patients across post-Soviet borders in a historic, cultural and intrinsically sociolinguistic perspective, consider the following excerpt from an interview with a Lithuanian healthcare entrepreneur, who is a key figure in a public agency established to promote health tourism in the country (Delfi.lt ${ }^{1}$ 2013, in Muth 2017: 408):

[...] It is the East, because towards those countries there is no language barrier, they are similar to our mentality, we also have a fairly good reputation from past times in Soviet times Lithuania was known for its high-quality medical services. In the eyes of the West, we do not [have such reputation].

For scholars of history, nationalism and post-Soviet language policy in particular, this statement might come as a surprise, given that for the past 25 years political discourses in Lithuania have significantly shifted away from any references to the country's Soviet past, including oblivion of the role of Russian as the lingua franca of the former USSR. Instead, Lithuanian language and culture have become the cornerstones of Lithuanian national narrative (Baločkaitė 2014; Grumadienè 2005). However, despite the frequent exhibition of nationalist ideologies in political discourses, economic crisis and demographic change led to the promotion of Lithuania as a destination for Russian-speaking medical tourists (Muth 2017a). And this is where language commodification offers an analytical lens to make sense of such developments. It helps to show that in the current economic order language is no longer framed exclusively in political or national terms, but evolves into a means of market expansion and a manifestation of capital (Heller and Duchêne 2012). In the Lithuanian example, the promise to profit from a lucrative medical-tourism market led to the emergence of Russian as an added value because the proficiency of medical staff in Russian attracts Russian-speaking patients. And as the above quoted excerpt implies, common language in combination with similar men-

${ }^{1}$ Original text in Lithuanian: 'Būtent Rytų, nes su šiomis šalimis nèra kalbos barjero, mūsų panašus mentalitetas, taip pat turime pakankamai gerą reputaciją iš senų laikų - Lietuva nuo sovietmečio garsèjo kaip kokybiškų medicinos paslaugų šalis. Vakaruose mes tokio ịvaizdžio neturime'. http://www.delfi.lt/news/daily/health/idomus-ne-tikbaltarusiams-lietuvos-laukia-pasiligojusiu-rusuantpludis.d?id=62302823 (accessed 08.06.2017). 
talities and a shared history with the Russian-speaking world are beneficial for the Lithuanian economy, with similar situations found throughout the former Soviet Union. While for reasons of prestige, trust and attractiveness for patients Lithuania is portrayed as firmly belonging to West European healthcare systems, all of its (local) medical personnel is styled as bilingual Lithuanian and Russian and having adequate skills for taking care of Russian-speaking patients (Muth 2017a). However, commodity values are fleeting and just as a language may suddenly become a means for market expansion and capital gain, the reverse may also happen. A case in point is a sudden downturn in the fortunes of Russian: the years 2014 and 2015 marked a turning point when the niche product of medical service in Russian within 'European' settings and performed by local Lithuanian workforce became less desirable, following Russia's economic crisis. Given the devaluation of the Russian ruble and decreasing numbers of Russians travelling abroad, it seemed that Russian had irreversibly lost its commodity value as potential consumers disappeared. But as of late 2016, tourist numbers rose and Russians once again began to travel abroad, benefiting from Lithuania's healthcare industry and appreciating services rendered in Russian (Connell 2016).

While being only a small part of the puzzle of language commodification, this trajectory in the popularity of Russian connects to a central argument research within this field has brought forward, namely that language seems to be indicative of widerranging political and economic processes and developments (Heller 2010; Kelly-Holmes 2005; Pavlenko 2017; Tan and Rubdy 2008). With regard to Russian this is, indeed, best exemplified by the changing commodity value of the language within the past two decades, and in particular starting with the new millennium and the consolidation of the Russian economy after the end of the Yeltsin-era. While after the breakup of the Soviet Union, the status and use of Russian were in decline in most former Soviet Republics, as well as throughout Eastern Europe as a whole (Pavlenko 2008, 2013, 2017), rising oil prices and a recovering Russian economy saw Russian to become a language of prestige. On the territory of the former USSR, knowing Russian once again meant gaining access to an increasing media production, Russian-language websites and internet content (Uffelman 2013). Moreover, in many former republics it remained an essential linguistic resource in the economy and promised access to the Russian labor market to individuals with adequate Russian skills. A possibility of customizing services to a large group of potential clients by offering them to Russian-speakers in their language triggered a number of shifts, especially in tourism as one of the key sites where language commodification takes place.

In order to understand what Russian-language commodification is, what it implies and how it changes society, another perspective, taken from outside the countries of the former Soviet Union is also needed. Most importantly, thanks to economic recovery, rising wages and the formation of an urban middle class with significant spending power, Russian-speakers began to travel to popular holiday destinations in Western and Southern Europe, and the Mediterranean. The flourishing of both mass- and individual tourism for leisure, culture and shopping caused service providers in the tourism industries of Egypt, Finland, Germany, Greece, Italy, Spain, Switzerland and Turkey to make efforts 
to accommodate the needs of their new clients. They began investing in Russian by hiring Russian-speakers and/or by advertising services in Russian (Pavlenko 2012, 2017). In addition, specialized services were made available in Russian, especially in medical tourism and finance (Muth 2017a). But with the spiraling of the Ukrainian politic crisis, the annexation of Crimea, and Russia's entry into the Syrian Civil War that occurred against the backdrop of falling prices for energy commodities, the fortunes of the Russian language seemed to change. At the end of 2015, tourist numbers of Russians travelling abroad were in decline. Among those badly hit by these events were service providers and individuals who had made significant investments in Russian language acquisition. Another recent example revealing that language commodification should be viewed in the context of political and economic events is disagreements between Russia and Turkey in early 2016 which effectively resulted in a drastic drop in Russian mass-tourism to Turkey, thus making services in Russian redundant. As a result, proficiency in Russian lost added value. However, such change of fortune does not necessarily mean that once a language ceases to provide an added value because of a disappearing consumerbase, it leaves the market for good. In fact, in the case of Russian tourism to Turkey, in fall 2016 Russian speakers came back to explore the Turkish Mediterranean Coast, and providers of various tourist services continued where they had left some months earlier.

\section{THEORETICAL BACKGROUND}

Going back to the examples given in the previous section, what the Lithuanian healthcare industry ultimately shows lies at the heart of our understanding of the commodification of languages and speakers. More explicitly, it highlights the changing role of language that is not exclusively a cornerstone of the imagined, linguistically homogenous, 19th century nation state (Anderson 1991), but equally an expression of the global new economy that to a large extent is characterized by the emergence of new conditions for the production of language practices (Heller 2010; Heller and Duchêne 2012). Capitalism in its current form is marked by an increasing exchange of goods, services and labor on a global scale resulting in language becoming a distinctive product, in particular, in education, the service industry, tourism and international trade. Most comprehensively, the conditions for language commodification have been put forward by Heller (2010), who views it as a work product and as a process closely related to

[...] (a) capitalist expansion or globalization, requiring the management of communication (involving producers, consumers, and national or supranational regulating bodies) across linguistic difference; (b) computerization of the work process, requiring new kinds of language and literacy skills among workers; (c) the growth of the service sector, in largely communication-based form; and (d) responses to the saturation of markets in the form of the development of niche markets (which require localized approaches often including a focus on linguistic specificity) and of the use of symbolic, often linguistic, resources to add value to standardized products (104).

This implies that from a broad perspective, the commodification of language transforms and mobilizes symbolic capital to become interchangeable with material capital 
and as such is firmly embedded in the global new economy and its logic of perpetual market expansion and capital gain (Heller 2003; Heller and Duchêne 2012; Rubdy and Tan 2008). This also implies that linguistic forms and practices evolving in the process of language valorization express ideologies manifesting social hierarchies and as such mark a shift towards neoliberalism and the entry of semiotic products of nationalism (such as language) into processes of commodification (Heller and Duchêne 2016: 141). Commodification of languages and speakers is tied to current political and economic conditions within communities (Gal 1989; Heller 2003; Irvine 1989), viewed as a conception and paradigm commodification deepens our understanding of how language and identity turn into a symbolic capital. They do not only frame meaning and social relations, but also become economically viable resources and marketable commodities. This neither challenges prevailing language ideologies nor does it question the prevalence of images of historic continuity of nations characterized by a uniform population, culture and language per se, but instead, appropriates and expands them towards the economic sphere (Heller 2010, 102; Heller and Duchene 2016). Here, tensions and struggles that emerge around language move away from political to economical frames, thus, as Heller (2010) puts it, "[...] changing the nature of discourses that legitimize power and the nature of criteria used in social selection, and therefore also having an impact on the constraints on access to symbolic and material resources for actors occupying different social positions" (102).

As a paradigm, commodification of languages and speakers shares two fundamental expressions, those of a technical skill and of a feature of authenticity and distinction for otherwise saturated markets (Coupland and Garrett 2010; Urciuoli and LaDousa 2013). Communication and customer-based services are now offered on a global scale, resulting in increasing communication across cultural and linguistic boundaries that call for an explicit and oftentimes rigid management and policing of speakers. So language commodification can be viewed as a work process as well as a work product with language being a measurable skill (Boutet 2008; Duchêne 2009; Heller 2003, 2010). In addition, language commodification can also find its expression in images of authenticity, where language (or particular forms of language) add symbolic value to products, making standardized goods and services "[...] special by being marketed as local, authentic, and in some ways unique products with limited distribution" (Cavanaugh and Shankar 2012; Coupland and Garrett 2010; Heller 2010: 350). This is not necessarily explicitly related to language production as such (like in a call center or tourism agency that offer services for speakers of particular languages) but instead, takes advantage of specific accents or dialects which contribute to the product value by highlighting their authenticity, uniqueness and origin. Here, uniqueness and authenticity entail questions about language use and cultural preferences of (desired) consumers from different markets and how those may (or may not) hold an added value for particular products or services (Cavanaugh and Shankar 2012; Heller 2010). This volatility (Duchene and Heller 2016) is also at the heart of current debates on language commodification and the role of language in neoliberalism (Holborow 2007, 2015; Muth 
and Del Percio 2017), as it highlights the uncertainties that go along with global capitalism and the new economy. Language may gain but then again loose its market value and offering services in a certain language or — as an individual — deciding to take a language course - may add symbolic (and subsequently economic) value or would mean a decisive skill for a professional career (Park 2016). However, apart from valorization there are reverse phenomena and while at a particular moment in time speaking a particular language constitutes a competitive advantage for enterprises and individuals alike, market conditions are rarely stable but quickly change and result in opposite phenomena and the devaluation of linguistic resources.

In order to grasp how languages can be turned into potentially valuable commodities, let us now revisit spheres of human activities favorable for language commodification. In the following section I will outline contexts of language production and consumption (Gal 1989; Irvine 1989) that clearly show that language does not only reflect social order and social constellations but plays an important part in their further reproduction (Heller 2010: 102). In that respect, looking at language through the lens of commodification enables us to explore language ideologies and analyze how they are negotiated, appropriated and reproduced when frames are shifting from the political towards the economic one.

\section{WHERE DO WE FIND LANGUAGE COMMODIFICATION?}

So far scholarly work on the commodification of languages and speakers has focused on the domains in which language use plays an important part in the neoliberal economy (Cavanaugh and Shankar 2014; Heller 2003; Heller, Pujolar and Duchene 2015; Tan and Rubdy 2008). Analysis of various aspects of language commodification started in those geographic areas which gave ample data for the study of interaction of several languages and language-focused work (Muth and Ryazanova-Clarke 2017; Pavlenko 2012). Heller singled out five areas in which the economic value of languages and speakers, become particularly salient, namely tourism, marketing and advertising, language teaching and translation, call centers and performance art (2010: 107-110).

Among these, tourism is arguably the most prominent and also the most comprehensively-covered field in this special issue. Language skills of the employees are salient for both package tourism, as a product of mass-consumption and for niche forms of travelling tailored to specific interests of individuals, such as extreme sports, adventure- and heritage tourism. The latter shows most vividly the authenticating value of language. Linguistic minorities emerged as a product of the $19^{\text {th }}$-century nation building and identities that evolved in this process are now commodified and marketed (Heller 2010; Coupland 2010). Furthermore, in newly emerging niche markets, and in medical tourism in particular, the required language proficiency and an individualized approach in serving clients/patients, as well as stereotypical representation of a country offering services are used in promotional discourses. A case in point is promotion of the image of multilingual Switzerland by the country's tourism industry as discussed in Del Percio 2016 and Muth 2017b. 
There are other forms of mobility which cannot be considered tourism per se but still involve language work and travels. These are cross-border trips for trade and shopping, as discussed in Urry 2007, and markets which become sites of translanguaging where salespeople's ability to speak to the clients in their language gives the former a competitive advantage. See, e.g., Grigorichev and Guzei in this issue and Suryanarayan's (2017) account of a Delhi market that gained popularity among visitors from countries of the former Soviet Union because of its share of Russian-speaking traders.

In this respect, marketing and advertising are to some extent intertwined with tourism, highlighting the "localization dimension of globalization" (Heller 2010; Kelly Holmes 2005) and pointing towards the promotion of local identities within global markets as described by Coupland and Garrett (2010) in relation to the commodification of heritage culture by descendants of Welsh settlers in Argentinian Patagonia. Similarly, Brennan (2017) describes efforts to promote Irish language learning among small business owners in the Republic of Ireland in order to sell 'authentic' tourism products and at the same time to create social cohesion within local communities through grassroots language activism. When viewed in the context of language production, advertising results in the promotion of culturally specific products and services that may — or may not - convert symbolic value to capital gains by discursively constructing them as authentic and unique. Furthermore, multilingualism as such may have a commodity value in the form of symbolic cosmopolitanism (Heller 2010: 108). In a similar vein, new forms of global movements such as the circulation of domestic workers and care givers presupposes mastering specific linguistic repertoires as part of occupational training. Studying these movements and the people involved allows researchers to examine the language these people use in their work and their linguistic biographies through the lens of commodity value. Exemplarily, this is examined by Lorente (2016) in her research on English-speaking domestic workers from the Philippines who are trained in English to serve English-speaking families in Singapore.

The third economic sphere, language teaching, is closely related to tourism and marketing. Language teaching sets the conditions and norms for language production while at the same time highlights language both as a process and as a product of work (Heller 2010: 108). Indeed, we may now argue that language teaching and learning have become central elements in debates about language commodification in the light of global mobility, migration movements and tourism flows (Cameron 2012). This trend has manifold manifestations and can relate to 1) language learners seeking (or forced) to acquire potentially 'valuable' languages as Park (2016), and Piller and Cho (2013) describe in their research into English in South Korea, 2) the need to acquire popular tourist languages to adequately cater to tourists in the language of their choice, a phenomenon discussed by Sharma and Phyak (2017) with regard to the Nepali tourism industry, or 3) the form of particular language policies within transnational faith-based communities as explored by Bolander (2017) in her research into English learning among Ismaili in Tajikistan and Pakistan.

In a similar vein, Translation as the fourth economic sphere where scholars address the commodity value of languages and speakers is inseparable from global mobility 
and tourism. From a broad perspective, translation industries are intertwined with notions of language policy and as such they originate from modernist ideas as to how to manage ethnonational boundaries within multilingual political entities (Heller 2010: 109). Expertise in managing these multilingual networks offers a good chance to capitalize on translation services. At the same time, examining translation as a cultural practice, we see that speakers with certain cultural or linguistic backgrounds and life trajectories considered to be valuable experiences within the field may be regarded as more authentic, trustworthy or skilled than their other colleagues. Such attitudes were observed in the research in Swiss hospitals into the commodity value of Russian (Muth 2017b). While in general, Russian-speaking patients welcomed the availability of Russian-speaking medical staff and hospitality workers, they seemed to prefer those speakers who either acquired proficiency in Russian as a second or third language, or native speakers of Russian who lived in Switzerland for a considerable amount of time (Muth 2017b: 15).

The call center industry is the fifth economic sphere Heller (2010) describes where we can observe language commodification. Call centers operate on a global scale and are oftentimes geographically detached from their target markets with language production frequently characterized by standardized communication requiring particular languages, sets of practices and forms typical of specific geographic contexts (Boutet 2008; Cameron 2001). As Duchêne and Flubacher (2015) highlight in their research into the evolution of the call center industry in the German-French bilingual city of Biel/Bienne in Switzerland, this oftentimes relates to economic decline and structural change within bi- and multilingual communities. Attracting 'communication' industries by availability of skilled and low-cost workforce with multilingual repertoires, multilingualism itself becomes a commodity on global markets.

Lastly, performance art relates to commodified products that employ 'authentic' musical and linguistic resources (Heller 2010: 110) within standardized transnational frames (for instance Russian-language hip-hop). In a broader context, Uffelmann (2013) showed that with regard to the Russian-language internet ('Runet'), these forms of cultural production may gain an added value in the countries of the former Soviet Union through the use of Russian since audiences can relate to this language and for many it is the second or even the first language.

These examples notwithstanding, the commodification of languages and speakers is neither exclusive to the economic spheres outlines here, nor is it bound to happen as soon as individuals or entrepreneurs deem certain communicative resources valuable within a local or global contexts. In fact, establishing a potential commodity value of a language or of those who speak is a prerequisite to adding value to a particular product or service, since language commodification is shaped by a broad social, political, and economic context. All the articles included in this special issue address a particular sphere, context, topic or moment in time that will ultimately help us to better understand where and why Russian gets valorized and constitutes an added value. To a certain extent all contributions examine the relationship of language with mobility and the global movement of people, goods and services characteristic of the current form of neoliberal economy, which is also an expression of fundamental tensions emerging when language is recast as an economic resource (Heller and Duchêne 2012; Pavlenko 2017). Furthermore, all contributions point towards a set of motivations to invest in Russian 
showing them from the perspective of individuals acquiring various levels of proficiency to serve Russian-speaking markets, and of corporate stakeholders who see Russian speakers as a lucrative customer base, as well as from the position of national or supranational organizations. Viewing commodification from these different angles contributes to the awareness of the economic 'possibilities' which Russian offers to national economies in times of economic crisis and structural economic change.

\section{COMMODIFYING RUSSIAN: THIS ISSUE}

The papers of this special issue bring together case studies that address the commodification of Russian from various angles and within various geographical contexts, all of them taking a perspective of the use of Russian outside of countries where it is a national language or a language of wider communication. More precisely, as Pavlenko (this issue) states, all contributions document the historical moment when Russian became one of the most popular languages in the international service industry and within the framework of transnational leisure- and shopping tourism. Furthermore, the contributions to this special issue underscore how geopolitical, economic, social, and demographic factors influence the processes of commodification and decomodification of the language and - from an economistic perspective - draw attention to the motivations that lie behind attempts to turn Russian into a 'valuable' communicative resource. Lastly, the papers explicitly or implicitly investigate the role of teaching and learning Russian for commodification, pointing towards both state- and corporate policies that promote the learning of Russian, or individual motivations to acquire various degrees of proficiency in the language to address market-driven demand that calls for the linguistic accommodation of Russian-speaking tourists.

The first contribution of this special issue by Pavlenko is entitled "Linguistic landscapes and other sociolinguistic methods in the study of Russian language abroad." Pavlenko's paper is intended to be a practical guide for doing sociolinguistic research on Russian-use in the social sphere, drawing a distinction between primary and secondary data. She argues that primary data are central for any meaningful sociolinguistic research into the use of Russian abroad enabling us to address the following questions: (1) in what contexts is Russian given preference when compared to other languages and in which circumstances is Russian used on equal footing when compared to English and/or local languages; (2) who is engaged in language work (language labor), for instance, in the form of translated (tourism) materials and the provision of language services; and (3) what role do geopolitical and social factors play in efforts to commodify Russian abroad. In particular, ways to obtain primary data in research include observations, linguistic landscaping, ethnographic fieldwork, and sociolinguistic interviews.

While observations broadly refer to an impetus scholars gain by taking note of interesting sociolinguistic phenomena (such as the appearance of Russian-language signs in tourism destinations), linguistic landscaping refers to the systematic collection of written Russian texts visible in the public sphere. Drawing from seminal work in the field of linguistic landscape, Pavlenko illustrates how the documentation of Russian on signs (for instance in tourism destinations frequented by Russian travelers) enables us to draw conclusions on the status of Russian and the domains of its use. Furthermore, this approach allows us to contrast the use of Russian vis-à-vis other languages that may also 
represent an inherent exchange value, in particular in the tourism industry. Clearly, linguistic landscape research might be conducted in a number of ways, each allowing us to draw unique conclusions on the utilization of Russian. First, this refers to quantitative approaches that call for a systematic and traceable collection of images of signs in order to count frequencies of occurrence of Russian. Secondly, it highlights qualitative approaches that require an in-depth analysis of displays of written language in the public sphere in order to elucidate in which instances Russian is used, by whom, and for what purpose. Therefore, the contexts in which Russian becomes part of linguistic landscape become an integral part of these studies. A combination of both approaches is also possible and beneficial, allowing the researcher to contrast quantitative data with a qualitative analysis of certain signs that in some way or other prove to be characteristic of or emblematic for a research site. Apart from addressing the question of representativeness of linguistic landscaping the combination of the two approaches has the advantage of providing insights into the motivations and investments individuals, enterprises and public actors, such as the state, are ready to make in order to profit from their ability to accommodate Russian speakers in Russian. This connects linguistic landscape research to ethnographic fieldwork (Marcus 1995; Smith 2005) which has become increasingly prominent in sociolinguistics in the recent years. Doing ethnography encompasses (written) field observations that are qualitative in nature and address multilingual practices in diverse settings. Russian language outside the nation came to play a role in hospitals, hotels, airports, shops and other service industry enterprises. Observations include viewing and listening to transactions in shops and monitoring institutional websites and websites related to tourism. Site monitoring is frequently undertaken at the beginning of a study, preparing grounds for further investigations.

Equally central in gathering primary data is the sociolinguistic interview. Interviews enable researchers to interrogate language workers, such as sales assistants, tour guides, shop assistants, as well as business owners, stakeholders involved in the tourism industry and policy makers, who are either proficient in Russian or who are otherwise involved in the commodification of Russian. Sociolinguistic interviews help us learn about work experiences and career trajectories of Russian-speaking service workers.

Pavlenko's notion of secondary data refers to information from academic literature and internet sources, as well as from demographic- and meta-economic data. In this context, consulting and evaluating demographic data on the number of Russian speakers in a given community or country can offer insights into the use of the language, while meta-economic data on tourism spending, enrollment in language classes and capital flows from Russia and post-Soviet countries have the potential to provide explanations as to why and in what particular contexts Russian is used abroad. This aspect of research is particularly salient when we explore how changing tourist flows (for instance in the wake of the Russian financial crisis) might translate into changing patterns of the use of Russian abroad and trigger its decommodification.

The second contribution to this special issue by Suryanarayan is entitled "The Role of Russian language workers in India's health-care sector". It addresses a fairly recent phenomenon of medical tourism, a site for the commodification of Russian already addressed in the introduction. Applying participant observation and questionnaires, the author conducted fieldwork in four private hospitals in the Greater Delhi area. These 
hospitals offer medical care to Russian-speaking tourists coming from Russia, Kazakhstan, Uzbekistan and other post-Soviet countries of Central Asia. Suryanarayan aims to find out how hospital administration and staff, including doctors, medical interpreters (mainly current or former university students of Russian), and patients perceive the quality of language work in medical settings. She demonstrates how Russian becomes part of a strategy of economic expansion by private healthcare providers. It is discursively constructed as a language that increases chances of employment for students of Russian, who might become independent healthcare brokers and successful entrepreneurs in the Indian medical tourism industry. Russian proficiency of the hospital staff contributes to patient flows from post-Soviet countries and provides an added value to healthcare services offered by each of the four hospitals.

The third contribution by Grigorichev and Guzei applies a socio-anthropological approach to the commodification of Russian. Based on in-depth analysis and rich description of the history and language practices at two ethnic markets, their research highlights how Russian is used as a contact language between traders and customers. The authors base their ethnographic observations on markets in Irkutsk, Russia as well as one market in Beijing, China and show, how communicative patterns evolve within the two research sites. While geographically apart and situated in entirely different immediate contexts, both sites can be considered as border spaces; furthermore, in both markets traders are usually ethnic Chinese and thus share Chinese (Putonghua) as their first language. Customers, however, are predominantly Russian-speaking, requiring linguistic accommodation. In fact, the Beijing market studied by the researchers has a longestablished reputation of being a Russian-friendly space, echoing Suryanarayan's (2017) account of linguistic practices at a Delhi market that caters to Russian-speaking shoppers and traders from post-Soviet countries. In that respect, the research sites are historically regarded as ethnic spaces of language contact, and the authors also show attitudes towards Russian-Chinese contact languages as well as their potential albeit rather limited market value. Grigorichev and Guzei's paper illustrates that the emergence and seemingly constant evolvement of contact languages in those markets has to be viewed in relation to the particular context of the Chinese-Russian borderland. Although the sites under study are not in immediate proximity to the border, market talk to a certain extent resembles communicative practices characteristic of the immediate borderland.

The fourth contribution brings the reader to the Middle East focusing on the linguistic landscape of Israel. In the essay entitled "Linguistic Landscape and what it tells us about the integration of the Russian language into Israeli economy", Yelenevskaya and Fialkova apply a multi-facet approach to the study of language in the public sphere with a specific focus on the effects of immigration of Russian speakers from the countries of the post-Soviet sphere to Israel. The authors employ three methods of data collection in their analysis and relate them to each other. These are (1) a conventional linguistic landscaping approach (2) analysis of Russian-language Israeli websites (3) ethnographic field notes taken during observations and interviews. All methods complement each other, but at the heart of the authors' analysis lies an investigation into the relationship between Russian displayed on signs and on webpages and the motivations by stakeholders to decide when to use Russian. The authors include in their analyses conversations with passersby, employees in government offices, salespeople, business owners 
and their clients. They inquired whether or not multilingual promotional discourses displayed on signs and websites were considered useful in serving clients; furthermore Yelenevskaya and Fialkova bring to the readers' attention the role of one-and-a half and second-generation immigrants in the language work required to cater to customers and clients in Russian in contexts as diverse as communication with state agencies, financial institutions, judicial system and entertainment. Finally, the authors demonstrate the use of Russian and Soviet cultural symbols as a marketing strategy.

With a similar focus on linguistics landscapes but with a more explicit historical perspective, Olnova's contribution "Russian in Northern Norway: Historical, cultural and economic links' revisits the notion of borderland, providing an account of the language situation in Kirkenes, a town in Northern Norway. In recent years, Kirkenes has become a popular destination for shopping tourists from the Murmansk region. The article examines commodification of Russian in Kirkenes and links it to the emergence of a new economy and to the current policy of collaboration between Norway and Russia. The author traces attempts of local authorities to revive the historical 'Pomor trade'. She relies on linguistic landscape fieldwork based on (1) a corpus consisting of 100 digital pictures of shopfronts, road signs and instore images, (2) analysis of printed materials and official documents for Russian-speaking tourists (3) interview data with Russian tourists and members of the local population. As discussed in Olnova's essay, the situation in Kirkenes illustrates the transformation of the 'old economy' into a new one that is characterized by a structural economic change and a rise of the service industries. Transforming a former mining town into a tourist attraction where Russian-speaking visitors can expect services in Russian, Kirkenes emerges as one of the centers of Russian-Norwegian collaboration and cross-border exchange, a context that is primarily visible through the display of Russian in the linguistic landscape of the town.

As has been discussed earlier, periods of language valorization can be followed by decline. This volatility is shown in Cabal-Guarro's work on the commodification and possible decommodification of Russian in Catalonia. Thanks to its natural beauty, architectural gems and seaside resorts this region of Spain has become a tourist destination popular among travelers from countries of the former Soviet Union. In his paper "Is Russian decommodifying in Catalonia?" the author traces instances of commodification of Russian in the Catalan tourism industry through semi-structured interviews with shop owners, questionnaires for Russian-speaking service workers, as well as linguistic landscape data from Barcelona and Salou, and compares his findings with statistical data on tourist flows from Russia. The aim of this contribution is to trace the commodity value of Russian over time against the backdrop of fluctuating numbers of Russian-speaking visitors. In the context of this special issue, Cabal-Guarro's analyses will contribute to a better understanding of how political and economic events affect valorization of languages, making their speakers visible, and how sensitive the linguistic market is to changes in (geo)political developments.

The remaining two contributions of this special issue are meant to provide valuable insights into two aspects not explicitly dealt with in the other research presented in this special issue. On the one hand, in their paper "Aspects of commodification of Russian in Finland", Viimaranta, Protassova and Mustajoki trace the history of Russian in Finland and provide insightful observations into the current patterns of use of the language in Finnish society, ranging from efforts to commodify Russian in order to serve Rus- 
sian-speaking tourists visiting the country, but also providing the perspective of Russians currently living in Finland. They argue that in recent years Russian became a significant asset on the local employment market, both for Russian-speaking immigrants and for the still relatively small number of Finns who can speak the language, aspects that are mirrored in a considerable demand among Russian-speaking parents in Finland for educational services to supplement the Finnish-medium school education for their children. On the other hand and connecting to education, in her contribution ""Retour" — An innovative resource for teaching the Russian language to tourism workers in countries of the European Union", Pencheva discusses the advantages of a self-study program for Russian-learning for service industries in the European Union. Designed as an online program and learning tool, "Retour" offers the possibility to acquire Russian skills that are specific to the tourism industry. Pencheva concludes that the tourism sector in the EU is interested in training Russian in the field of tourism in order to capitalize on their communicative resources and in order to expand their tourism industries towards Russian-speaking markets.

All the case studies outlined here make us pose a question: what are the theoretical implications and practical applications of the research into commodification of the Russian language? As Pavlenko reminds us (see this issue), the current commodification of Russian presents us with an opportunity to study language in new social and geographic contexts and examine how the status and function of Russian have changed since the disintegration of the Soviet Union. At the same time we can see how commodification intersects with the global rise of the neoliberal economy, and how market considerations spread to all domains of social life. Moreover, we find further proof that Russia has a special economic, historic and cultural role in the post-Communist world order. We need more extensive research into how value is inscribed to Russian within transnationally operating service industries and how Russian has become a commodity along with English and Chinese. Today it can be regarded as one of the most popular and widely used languages within transnational service industries, including leisure tourism, medical travel, transportation, real-estate, and marketing (Aref'ev 2017; Pavlenko, this issue). Motivations to invest in Russian by individuals learning and perfecting the language or by organizations as an expression of corporate or governmental policies (for instance by strategically employing workers proficient in Russian) largely relate to economistic motifs, fueled by projections of tourism flows and spending power of Russian speakers travelling abroad. Here, investments into Russian may provide an added value to services offered in that language, in turn highlighting where and for what reasons Russian gained value in wider social, economic and political contexts. As this special issue shows, both circumstances and consequences of commodification of Russian and its speakers are closely related to the effects of globalization, to the growing mobility of Russian speakers and Russian-language workers, as well as to the mobility of service industries that now operate on a global scale and continue to expand into new markets.

However, as Pavlenko highlights, enquiries into these phenomena require a clear understanding of appropriate research methods and call for empirically-oriented approaches that see language in its immediate societal context. Similarly, they require well-formulated research designы and data sampling methods that are both transparent and reproducible. Indeed, if this is the case, sociolinguistic research addressing the use of Russian 
abroad and the commodification of Russian language and speakers offers unprecedented opportunities for scholars to study those moments in time when a language evolves into a commodified communicative resource.

\section{RU}

После успешного двухтомного выпуска, посвященного анализу дискурса (Понтон, Ларина 2016, 2017), мы предлагаем вниманию читателей журнала «Вестник Российского университета дружбы народов. Серия: Лингвистика» очередной спецвыпуск, который в этот раз посвящаем новой теме, активно интересующей социолингвистов, - коммодификации языка. Мы рассмотрим само явление коммодификации языка, его причины и методы исследования, а также проанализируем конкретные проявления коммодификации русского языка в разных странах мира. Статьи этого специального выпуска объединяют исследования коммодификации русского языка с разных точек зрения и в разных географических контекстах. Авторы рассматривают употребление русского языка за пределами России - в Литве, Индии, Израиле, Испании, Норвегии, Китае, Финляндии и Болгарии - и приводят данные, свидетельствующие о том, что русский язык становится одним из наиболее популярных языков в сфере отдыха, торговли и туризма. Также они показывают, как геополитические, экономические, социальные и демографические факторы влияют на процессы коммодификации и декоммодификции языка, а с экономической точки зрения обращают внимание на мотивацию, лежащую в основе попыток превратить русский язык в ценный коммуникативный ресурс. Наконец, они прямо или косвенно исследуют роль преподавания и изучения русского языка для коммерческих целей, указывая как на государственную, так и корпоративную политику, способствующую изучению русского языка, а также личную мотивацию для овладения русским языком в той или иной степени с целью удовлетворения запросов рынка и оказания языковых услуг русскоязычным туристам.

\section{1. ЧТО ТАКОЕ КОММОДИФИКАЦИЯ ЯЗЫКА И ПОЧЕМУ ЛИНГВИСТАМ ВАЖНО ЕЕ ИЗУЧАТЬ?}

Почему лингвистам важно изучать коммодификацию языков? Почему мы считаем важным обратить внимание на меняющуюся роль языка в современных социально-экономических условиях, которые характеризуются растущим обменом товарами, услугами, трудовыми ресурсами и возникновением глобальной неолиберальной экономики, создающей возможности для коммодификации практически всего, включая язык? И, наконец, какие противоречия подобное переосмысление языка в экономических условиях может вызвать и каковы последствия происходящих изменений? Эти вопросы лежат в основе специального выпуска журнала «Вестник Российского университета дружбы народов. Серия: Лингвистика», и для их решения мы должны обратиться к роли языка в обществе и тому, какие она претерпела изменения, а именно - как язык, являющийся отличительной характеристикой национального государства, стал рассматриваться как ценный коммуникативный ресурс. Основная идея, впервые выдвинутая канадским социолингвистом Моникой Хэллер (Heller 2003) и швейцарским социолингвистом Александром Душеном (Duchêne 2009, 2011, 2015), состоит в том, что, языки, стратегически 
используемые как средство маркетинга, при наличии говорящих на них людей могут создавать прибавочную стоимость продукта или услуги.

Для иллюстрации сказанного обратимся к этнографическому исследованию, проведенному мной (Muth 2017a) в Литве, бывшей советской республике, которая в последние годы стала популярным направлением медицинского туризма для русскоговорящих из Беларуси, Калининградской области и других западных регионов России. Чтобы понять это явление в историческом, культурном и социолингвистическом контексте, рассмотрим следующую выдержку из интервью литовского предпринимателя в сфере здравоохранения, также являющегося ключевой фигурой государственного учреждения, созданного с целью продвижения медицинского туризма в стране (Delfi.lt ${ }^{1}$ 2013, Muth 2017: 408):

[...] Это восток, потому что между этими странами отсутствует языковой барьер, они имеют схожий с нашим менталитет; кроме того, мы обладаем достаточно хорошей репутацией, унаследованной из прошлого - в советское время Литва славилась высококачественными медицинскими услугами. В глазах Запада мы выглядим иначе.

Для тех, кто изучает историю, национализм и постсоветскую языковую политику, это утверждение может стать неожиданностью, учитывая то, что за последние 25 лет политический дискурс в Литве в значительной мере дистанцировался от любого упоминания о советском прошлом страны, в том числе от воспоминаний о том, что русский язык использовался в качестве лингва-франка в бывшем СССР. Вместо этого акцент делался на том, что литовский язык и культура являются краеугольным камнем национальной идеи (Baločkaite 2014; Grumadiene 2005).

Однако, несмотря на частые проявления националистической идеологии в политическом дискурсе, экономический кризис и демографические изменения привели к популяризации Литвы как привлекательного направления медицинского туризма для русскоязычных (Muth 2017a). Здесь языковая коммодификация предлагает аналитический инструмент, помогающий понять эти изменения и показать, что в современных экономических условиях язык больше не характеризуется исключительно политическими или национальными терминами, а становится средством расширения рынка и его капитализации (Heller and Duchêne 2012).

В ситуации с Литвой перспектива извлечь выгоду из прибыльного медицинского туристического бизнеса сделала русский язык дополнительным преимуществом, а владение медицинским персоналом русским языком стало фактором, привлекающим русскоязычных пациентов. Все это, вместе со схожим менталитетом и общей историей Литвы с русскоязычным миром, как подчеркивается в процитированном выше отрывке из интервью, нашло отклик у говорящих на русском языке на территории бывшего Советского Союза. Хотя с позиций престижа, доверия и привлекательности для пациентов Литва прочно ассоциируется с западноевропейскими системами здравоохранения, весь местный медицинский персонал

${ }^{1}$ В оригинале на литовском языке: 'Būtent Rytų, nes su šiomis šalimis nèra kalbos barjero, mūsų panašus mentalitetas, taip pat turime pakankamai gerą reputaciją iš senų laikų — Lietuva nuo sovietmečio garsėjo kaip kokybiškų medicinos paslaugų šalis. Vakaruose mes tokio ịvaizdžio neturime'. $\mathrm{http}$ //www.delfi.lt/news/daily/health/idomus-ne-tikbaltarusiams-lietuvos-laukia-pasiligojusiu-rusuantpludis.d?id=62302823 (accessed 08.06.2017). 
позиционируется как двуязычный, т.е. говорящий на литовском и русском языках, и имеет опыт работы с русскоязычными пациентами (Muth 2017a).

Тем не менее, товарные ценности преходящи. Это касается в том числе и языка, который может стать средством расширения рынка и прироста капитала, а затем потерять свою экономическую ценность. Так, в 2014-2015 гг. нишевый продукт медицинского обслуживания на русском языке в рамках «европейской» среды, предоставляемый литовским медицинским персоналом, стал менее востребованным на фоне экономического кризиса в России. Учитывая девальвацию российского рубля и сокращение числа россиян, выезжающих за рубеж, казалось, что русский язык в Литве навсегда потерял свою товарную стоимость по мере того, как сокращалось число его потенциальных потребителей. Но по состоянию на конец 2016 г. число русскоязычных туристов снова возросло, что принесло пользу здравоохранению Литвы, и, соответственно, услуги, предоставляемые на русском языке, снова оказались востребованными (Connell 2016).

Приведенные факты убедительно свидетельствуют о том, что язык тесным образом связан с широкими политическими и экономическими процессами и изменениями (Heller 2010; Kelly-Holmes 2005; Pavlenko 2017; Tan and Rubdy 2008). Что касается русского языка, то за последние два десятилетия мы можем наблюдать разновекторные изменения его товарной стоимости на фоне происходящих политических и социально-экономических процессов.

Если после распада Советского Союза статус и использование русского языка в большинстве бывших советских республик, а также на территории всей Восточной Европы в целом значительно снизились (Pavlenko 2008, 2013, 2017), то впоследствии рост цен на нефть и оживление российской экономики привели к тому, что русский язык стал возвращать свой международный престиж. Знание русского языка в странах бывшего СССР дает возможность получать доступ к русскоязычным СМИ, сайтам и интернет-контенту (Uffelman 2013). Кроме того, во многих бывших республиках он остается основным языковым ресурсом в экономике, а на личностном уровне дает доступ к российскому рынку труда. Возможность предоставлять услуги на русском языке привела к ряду изменений, особенно в сфере туризма как одной из ключевых площадок, где происходит коммодификация языка.

Чтобы глубже понять, что представляет собой коммодификация языка и как она меняется, большое значение имеет взгляд на это явление с более далекой дистанции - из стран дальнего зарубежья. Благодаря восстановлению экономики, росту доходов и формированию пусть и небольшого среднего класса, имеющего значительную покупательную способность, русскоговорящие стали путешествовать по популярным местам отдыха в странах Западной и Южной Европы, Средиземноморья и др.

Развитие как массового, так и индивидуального туризма с целью отдыха, знакомства с культурой других стран или шоппинга привело к активизации усилий поставщиков услуг в туристических отраслях Египта, Финляндии, Германии, Греции, Италии, Испании, Швейцарии, Турции и росту инвестиций в русский язык (путем найма русскоговорящих); увеличились также капиталовложения в рекламу услуг на русском языке (Pavlenko 2012, 2017). Расширялся и диапазон специализированных услуг, доступных на русском языке, особенно в области медицинского 
туризма и финансов (Muth 2017a). Однако в связи с началом украинского политического кризиса, участием России в гражданской войне в Сирии, а также падением цен на энергоносители ситуация, казалось, изменилась.

К концу 2015 г. число российских туристов, отправляющихся в зарубежные поездки, сократилось. Особенно сильно пострадали поставщики услуг и инвесторы, вложившие значительные средства в русский язык (в обучение русскому языку или в предприятия, предоставляющие услуги на русском языке). Кроме того, конкретные политические события еще раз показали необходимость рассмотрения коммодификации языка в политико-экономическом контексте. Например, конфликт между Россией и Турцией в начале 2016 г. привел к временному прекращению российского массового туризма в страну, что сократило потребность в обслуживании на русском языке и тем самым снизило его добавленную стоимость. Однако сокращение количества клиентов вовсе не означает, что язык окончательно теряет свою добавочную стоимость. Так, осенью 2016 г. в связи с изменением политической ситуации русскоговорящие туристы снова вернулись в Турцию.

\section{2. ТЕОРЕТИЧЕСКАЯ БАЗА}

Приведенный выше пример литовского здравоохранения раскрывает суть нашего понимания коммодификации языка. Он показывает меняющуюся роль языка, который подвергается воздействию новой глобальной экономики, создающей новые условия для языковых практик (Heller 2010; Heller and Duchêne 2012). Капитализм в его современном виде характеризуется все бо́льшим обменом товарами, услугами и трудовыми ресурсами в глобальном масштабе, в результате чего язык становится особым продуктом в образовании, в особенности в сфере обучения языку, в сфере услуг, туризма и международной торговли. Наиболее всесторонне условия для коммодификации языка были представлены в работе Хеллер (Heller 2010), которая определяет коммодификацию языка как продукт, так и процесс, тесно связанные с

[...] (а) капиталистической экспансией, или глобализацией, требующей управления коммуникацией (включая производителей, потребителей и государственные или надгосударственные регулирующие органы) в условиях языковых различий; (б) компьютеризацией рабочего процесса, предусматривающей необходимость новых видов языковых навыков и грамотности работников; (в) ростом сферы услуг, в значительной степени основанной на коммуникации и (г) развитием нишевых рынков (требующих участия местных торговцев, которые уделяют внимание приобретению языковых навыков) и использованием символических, а также лингвистических ресурсов для повышения ценности стандартных товаров (Heller 2010: 104). (пер. редколлегии).

Это подразумевает то, что в более широком смысле коммодификация языка трансформирует и мобилизует символический капитал с целью сделать его взаимозаменяемым с материальным капиталом, в силу чего коммодификация становится неотъемлемой частью новой глобальной экономики и непрекращающегося роста рынка и прироста капитала (Heller 2003; Heller and Duchêne 2012; Rubdy and Tan 2008). Это означает, что языковые формы и практики как результаты валоризации языков являются выражением идеологий и отражают социальные иерархии, что фактически подразумевает сдвиг в сторону неолиберализма и вхождение семиотических продуктов (языка) в процессы коммодификации (Heller and 
Duchêne 2016: 141). Коммодификация языков тесно связана с существующими политико-экономическими условиями внутри сообществ (Gal 1989; Heller 2003; Irvine 1989). Если же мы рассматриваем коммодификацию как концепцию и как парадигму, то она помогает понять, как язык в качестве символического капитала не только формирует значение, социальные отношения и личность, но и становится экономически жизнеспособным ресурсом, превращая языковые навыки в востребованный товар. Вышесказанное не оспаривает превалирующих языковых идеологий и не ставит под сомнение преобладающие представления об исторической преемственности наций, характеризующихся единообразием населения, культурой и собственно языком, а соотносит и расширяет эти представления, добавляя экономическую сферу (Heller 2010, 102; Heller and Duchene 2016).

Коммодификация языка как парадигма связана с двумя фундаментальными положениями, а именно, коммодификация 1) как технический навык и 2) как характеристика своеобразия и специфичности насыщенных рынков (Coupland and Garrett 2010; Urciuoli and LaDousa 2013). Коммуникация и услуги, ориентированные на покупателя, теперь предлагаются в глобальном масштабе, что в результате приводит к росту межкультурного и межязыкового взаимодействия, требующего четкого и зачастую жесткого управления и контроля над языковыми навыками говорящих, предоставляющих услуги. Здесь коммодификацию языка можно рассматривать и как рабочий процесс, и как продукт, где язык является измеряемым навыком (Heller 2010) и одним из самых значимых товаров (Boutet 2008; Duchêne 2009; Heller 2003, 2010).

В дополнение к этому языковая коммодификация выражается в том, что язык добавляет символическую ценность товарам и услугам и делает их «[...] особенными благодаря тому, что они продаются как местные, аутентичные и в некотором роде уникальные товары с ограниченным сбытом» (Cavanaugh and Shankar 2012; Coupland and Garrett 2010; Heller 2010: 350) (перевод редколлегии). Это не всегда касается использования языка (например, в колл-центре или туристическом агентстве, которое предлагает услуги для говорящих на определенных языках), а может быть связано с тем, как язык (например, акцент или диалект) влияет на ценность товара, указывая на его подлинность, уникальность и происхождение. Однако добавление ценности товару или услуге посредством языка (через его стандартизацию или подлинность) не является однозначным процессом, а характеризуется неопределенностью и фактически связано с меняющимися рыночными условиями, изменением потребительских предпочтений, а также насыщением рынка.

Уникальность и подлинность подразумевают использование языка и удовлетворение культурных предпочтений потребителей на разных рынках и ставят вопрос о том, может ли тот или иной язык обеспечить дополнительную ценность предлагаемых товаров и услуг (Cavanaugh and Shankar 2012; Heller 2010). Нестабильность ценности различных языков (Duchene and Heller 2016) лежит в основе споров о коммодификации языка и роли языка в условиях неолиберализма (Holborow 2007, 2015; Muth and Del Percio 2017), поскольку она указывает на неопределенность, сопутствующую глобальному капитализму и новой экономике. Язык может приобрести, а затем потерять рыночную стоимость, а предоставление или приобретение услуги на определенном языке может добавить символическую (и впоследствии экономическую) ценность или же будет означать приобретение 
важного навыка для профессиональной карьеры индивида (Park 2016). Однако помимо валоризации существуют и обратные явления. Хотя в определенный момент времени умение общаться на том или ином языке может представлять собой конкурентное преимущество как для отдельных индивидов, так и для предприятий, где они работают, рыночные условия нестабильны и быстро меняются, что может привести к девальвации лингвистических ресурсов.

Сказанное выше заостряет внимание на коммодификации языков в теоретическом аспекте. Чтобы осмыслить идею о том, что языки могут являться потенциально ценным товаром, обратимся к некоторым фундаментальным работам. Это поможет нам понять, в каких контекстах возникает коммодификация языка. Наша задача состоит в том, чтобы вычленить основные положения и аргументы ученых, занимающихся исследованиями коммодификации, и подчеркнуть то, что данная концепция может предложить социолингвистике и языкознанию.

Далее остановимся на некоторых основополагающих работах в этой области, которые рассматривают коммодификацию языка как явление, тесно связанное с конкретным контекстом употребления языка и потреблением (Gal 1989, Irvine 1989) в преобладающих политико-экономических условиях.

\section{3. ГДЕ ВСТРЕЧАЕТСЯ КОММОДИФИКАЦИЯ ЯЗЫКА?}

На текущий момент в рамках научной дискуссии о коммодификации языков рассмотрены те области человеческой деятельности, в которых использование языка имеет ключевую роль в условиях неолиберальной модели экономики (Cavanaugh and Shankar 2014; Heller 2003; Heller, Pujolar \& Duchene 2015; Tan \& Rubdy 2008). Анализ коммодификации языка начался в отдельных географических регионах, в которых изучалось взаимодействие конкретных языков (Muth \& RyazanovaClarke 2017; Pavlenko 2012). С учетом основных видов деятельности, на примере которых можно рассматривать и изучать коммодификацию языка, становятся наиболее заметными и существенными пять сфер экономики, в которых язык и его пользователи занимают особое место - туризм, маркетинг и реклама, обучение иностранным языкам и перевод, колл-центры, а также такой вид искусства, как перформанс (Heller 2010: 107-10).

Из всех вышеперечисленных областей наиболее важным и глубоко изученным в рамках коммодификации языка является туризм, как организованный, являющийся продуктом массового потребления, так и индивидуальный (например, экстремальные виды спорта, приключенческий или историко-культурный туризм). Последняя из перечисленных категорий широко использует язык как индикатор аутентичности языковых меньшинств, появившихся в результате построения государств в XIX в. На развивающихся сейчас новых туристических рынках требования к владению иностранными языками, а также индивидуальный подход в медицинской сфере, наряду с зачастую стереотипными представлениями о нации, используются в рекламном дискурсе для привлечения внимания к конкретным рынкам. Этот вопрос был рассмотрен Дель Перцио (Del Percio 2016) в исследовании, посвященном продвижению образа многоязычной Швейцарии в области туризма, особенно медицинского (Muth 2017b). 
Лингвисты проявляют также интерес к другим видам мобильности, которые, строго говоря, не относятся к туризму. Арри (Urry 2007), например, рассматривал в этом ключе поездки за границу за покупками. Такие явления также дают возможность изучать проблемы коммодификации языка, особенно в тех случаях, когда владение языком потенциальных клиентов дает конкурентные преимущества в торговле товарами и услугами. К числу таких исследований относится изучение рынка в работе Григоричева и Гузей (в этом выпуске), а также в статье Сурьянараян (Suryanarayan 2017), посвященной рынку в Дели, завоевавшему популярность среди посетителей из стран бывшего СССР благодаря наличию там русскоговорящих торговцев.

С этой точки зрения сфера маркетинга и рекламыл в некотором смысле переплетается с туризмом. Здесь наблюдается процесс глобализации в определенных регионах (Heller 2010; Kelly Holmes 2005) и продвижение местных особенностей и обычаев на мировой рынок, что было показано Куплендом и Гэрретом (Coupland \& Garrett 2010) в отношении коммодификации культурного наследия потомками валлийских поселенцев в аргентинской части Патагонии. Подобное явление изучает Бреннан (Brennan 2017). Он описывает попытки продвинуть изучение ирландского языка среди владельцев малого бизнеса в Ирландии, чтобы успешно продавать «аутентичные» туристические товары и услуги и установить социальное единство среди местных общин через активную языковую деятельность в широких массах.

Популяризация языка способствует продвижению культурно-специфических товаров и услуг, часто превращая их символическую ценность в реальную прибыль путем последовательного создания образа их уникальности и аутентичности. Помимо этого многоязычие, как проявление символического космополитизма, также может иметь товарную стоимость (Heller 2010: 108). Аналогично этому новые формы глобализации, например, мобильность домашнего обслуживающего персонала, сиделок и т.д., вынужденных приобретать языковые навыки в ходе профессиональной подготовки, также позволяют рассматривать языки и их пользователей через призму их товарной стоимости. Этот вопрос, например, был изучен Лоренте (Lorente 2016) в ее исследовании домашнего обслуживающего персонала из Филиппин, обученного английскому языку для работы в англоязычных семьях, проживающих в Сингапуре.

Третья рассматриваемая сфера экономики - обучение иностранныл языкам тесно связана как с маркетингом и рекламой, так и с туризмом. Обучение иностранным языкам определяет условия и нормы языкового употребления, в то же время выделяя язык как процесс и результат (Heller 2010: 108). Сейчас уже можно утверждать, что преподавание и изучение иностранных языков стали ключевыми элементами при обсуждении коммодификации языка в свете глобальной мобильности, больших потоков мигрантов и туристов (Сameron 2012). Диапазон исследований в этом направлении чрезвычайно велик и может касаться: 1) изучающих иностранный язык, стремящихся (или вынужденных) овладевать потенциально «ценными» языками, что описывают Парк (Park 2016) и Пиллер и Чо (Piller, Cho 
2016) в работах, посвященных английскому в Южной Корее; 2) необходимости овладевать основными языками туристической сферы для обеспечения достойного обслуживания прибывающих гостей на предпочитаемом ими языке, о чем пишут Шарма и Фяк (Sharma and Phyak 2017) в отношении туристической индустрии в Непале; 3) конкретной языковой политики транснациональных религиозных общин, в частности, мусульман-исмаилитов, изучающих английский язык в Таджикистане и Пакистане и исследованных в работе Боландер (Bolander 2017).

Четвертая сфера экономики, которую ученые исследуют с точки зрения товарной стоимости языков - перевод - тоже имеет отношение к глобальной мобильности и индустрии туризма. В широком смысле перевод связан с понятием языковой политики и, исходя из идей модернизма, регулирует национальные и этнические границы внутри многоязычных политических общностей (Heller 2010: 109). В этой сфере навык в установлении межъязыковых связей способствует капитализации переводческих услуг. Люди, имеющие общие культурные и языковые знания, вызывают больше доверия и считаются более опытными и знающими. Этот аспект был рассмотрен, в частности, в исследовании товарной ценности русского языка в швейцарских лечебных учреждениях (Muth 2017b). Кроме того, что русскоязычные пациенты в целом положительно оценили наличие русскоязычного персонала, они предпочитали контактировать с теми, кто изучал русский в качестве второго или третьего языка или прожил в Швейцарии довольно длительный период времени (Muth 2017b: 15).

Пятая экономическая сфера, где, по словам Хеллер (2010), мы можем наблюдать коммодификацию языка - это индустрия колл-цуентров. В наше время коллцентры уже достигли глобальных масштабов и зачастую географически удалены от целевых рынков, а употребление их сотрудниками языка нередко характеризуется стандартизированной коммуникацией, требующей знания определенных языков, набора дискурсивных практик и речевых форм, адаптированных под различные географические контексты (Boutet 2008; Cameron 2001). Работа колл-центров связана с экономическими процессами, как это показали Душене и Флюбачеp (Duchêne and Flubacher 2015) в своей работе об эволюции колл-центров в двуязычном немецко-французском городе Биль/Бьен в Швейцарии, где часто имеют место экономические спады и структурные изменения внутри двуязычных или многоязычных сообществ. Стремясь привлечь максимальное количество клиентов, отрасль связи приглашает опытных специалистов, владеющих несколькими языками. Как уже отмечалось, многоязычие само по себе становится товарной ценностью и в определенных экономических и социальных условиях может стать товаром на мировом рынке.

Наконец, перформанс относится к коммодифицированным продуктам, которые используют «аутентичные» музыкальные и языковые ресурсы (Heller 2010: 110) в рамках стандартизированных межнациональных видов искусства (например, хип-хоп на русском языке). В более широком контексте Уффельманн (Uffelmann 2013) продемонстрировал, что в отношении русскоязычного Интернета («Рунета») эти формы культурного производства имеют особую ценность среди бывших рес- 
публик СССР, так как русский язык является для многих пользователей вторым, а зачастую и родным языком.

Несмотря на все приведенные примеры, коммодификация языков не ограничивается исключительно этими сферами, а также деятельностью частных лиц и предпринимателей, которые оценивают важность коммуникативных ресурсов в региональном или международном аспекте. Установление потенциальной товарной ценности языка является предварительным условием увеличения цены на какой-либо товар и услугу, а коммодификация языка определяется более широким социальным, политическим и экономическим контекстом, как показывают исследования в предлагаемом читателю специальном выпуске.

Каждая из включенных в номер статей относится к конкретному временному, социальному и географическому контексту, что в конечном итоге помогает лучше понять, где и почему русский язык имеет особую ценность. В той или иной степени все представленные работы изучают взаимовлияние языка и глобальной мобильности не только людей, но и товаров и услуг, что характерно для нынешней неолиберальной экономики, и рассматривают язык, в первую очередь русский, как экономический ресурс (Pavlenko 2017, Heller and Duchêne 2012). Кроме того, во всех исследованиях приводятся причины, объясняющие, почему стоит инвестировать в русский язык: это и примеры успешного овладения русским языком частными лицами для работы на русскоязычных рынках; и мнения участников рынка, которые рассматривают носителей русского языка как покупателей, приносящих прибыль; и государственные и межгосударственные структуры, которые видят экономические возможности в использовании русского языка в период экономического кризиса и структурных изменений в экономике.

\section{4. КОММОДИФИКАЦИЯ РУССКОГО ЯЗЫКА: ВЗГЛЯД АВТОРОВ СПЕЦВЫПУСКА}

Открывает выпуск статья известного лингвиста А. Павленко «Языковые ландшафты и другие социолингвистические методы исследования русского языка за рубежом», которая является практическим руководством по исследованию использования русского языка в социальной сфере. Она предлагает делить данные, используемые в исследованиях коммодификации языков, на две группы - nepвичные и вторичные. Первичные данные - это данные, собранные исследователями. Они представляют особый интерес для социолингвистических исследований по использованию русского языка за рубежом и помогают ответить на следующие вопросы: (1) в каких местах и сферах обслуживания отдается предпочтение русскому языку, т.е. где русский язык используется наравне с английским или в большей степени, чем английский или местные языки; (2) кто занимается «языковой работой» (language labor), т.е. переводом материалов и предоставлением языковых услуг; и (3) как геополитические и социальные факторы влияют на востребованность языка. Основные методы получения первичных данных - это наблюдение, языковые ландшафты, полевые исследования и интервью.

Наблюдение особенно эффективно при изучении процессов, которые происходят на наших глазах (например, появление в туристических местах надписей 
на русском языке), и оно часто дает толчок к возникновению новых направлений в исследованиях. Социолингвистический метод систематического сбора и анализа таких текстов в общественных местах получил название языковые ландшафты.

Опираясь на языковые ландшафты, А. Павленко иллюстрирует, как документация русскоязычных надписей (например, в туристических местах, часто посещаемых русскоязычными туристами) позволяет сделать вывод о статусе русского языка и тех сферах, где он используется. Кроме того, этот подход позволяет противопоставить использование русского языка другим языкам, которые также могут представлять собой ценность, в частности в индустрии туризма. Исследования лингвистических ландшафтов могут проводиться по-разному, что дает возможность делать уникальные выводы об использовании русского языка. Прежде всего это количественный анализ, который требует систематического сбора надписей, с тем чтобы подсчитать частотность их появления; а также качественный анализ, требующий углубленного исследования письменных текстов в общественной сфере. Последний позволяет выяснить, в каких случаях используется русский язык, кем и для чего. Это дает возможность лучше понять, в каких контекстах русский язык становится частью языкового ландшафта. Кроме того, возможна комбинация обоих подходов, позволяющая сопоставлять количественные данные с качественным анализом, что дает исследователям особые преимущества.

Этнографические или полевые исследования (ethnographic fieldwork) (Marcus 1995, Smith 2005) в последние годы стали в социолингвистике особенно популярными. Они включают в себя (письменные) полевые наблюдения, которые носят качественный характер и учитывают многоязычные практики в тех сферах, где русский язык играет определенную роль, например, в больницах, гостиницах, аэропортах или магазинах. Данные исследования охватывают также анализ веб-сайтов, связанных с туристической мобильностью, что подготавливает почву для дальнейших исследований.

Важное место в сборе первичных данных, в том числе по коммодификации русского языка, занимают соииолингвистические интервью. Они позволяют исследователям опросить «языковых работников» (продавцов, владельцев магазинов, гидов и т.д.), которые либо владеют русским языком на профессиональном уровне либо иным образом вовлечены в коммодификацию русского языка. Социолингвистические интервью помогают узнать об опыте работы и мотивации лиц, а также частных и государственных служб, оказывающих языковые услуги.

Bторичные данныле, по мнению А. Павленко, - это данные, существующие в готовом виде - результаты предыдущих исследований, публикации в академических изданиях, статьи в средствах массовой информации, интернет-ресурсы, данные, собранные и опубликованные государственными организациями и частными агентствами.

Анализ и оценка демографических данных о численности русскоговорящих в том или ином сообществе или стране могут дать представление об использовании там русского языка. Экономические данные о расходах на туризм, зачисление в языковые классы или даже анализ потока капитала из России и стран бывшего Советского Союза могут объяснить, почему и где именно используется русский 
язык. Вторичные данные важны при учете того, как изменение потока туристов (например, после финансового кризиса в России) может привести к изменениям в использовании русского языка за рубежом и фактически к его декоммодификции (или наоборот).

Вторая статья этого номера - «Роль русского языка в сфере медицинских услуг Индии» (Н. Сурьянараян) посвящена коммодификации русского языка в относительно новой сфере экономической деятельности Индии, а именно в медицинском туризме. Используя этнографический подход, включающий наблюдение над работой четырех частных клиник Дели, которые предоставляют медицинские услуги гражданам России, Казахстана, Узбекистана и других центральноазиатских республик бывшего Советского Союза, автор показывает, кто и каким образом предоставляет языковые услуги в этих клиниках. С целью узнать о качестве и оценке употребления русского языка в медицинской сфере автор использует анкетирование для фокусных групп, среди которых: медицинские переводчики (главным образом это студенты и выпускники отделения русского языка университетов), администрация и медицинский персонал клиник, а также пациенты.

Н. Сурьянараян показывает, как русский язык становится важной составляющей этой развивающейся экономической сферы и дает студентам русского языка новые возможности трудоустройства и будущего профессионального роста. В то же время предоставление русскоязычных услуг в сфере медицинского туризма увеличивает поток клиентов из бывших советских республик и повышает качество их обслуживания.

Авторы следующей статьи - К.В. Григоричев и Я.С. Гузей - используют социо-антропологический подход к коммодификации русского языка. Основываясь на глубоком описании как истории, так и языковой практики этнических рынков Иркутска и Пекина и этнографических наблюдениях, они показывают специфику контактного языка («базарного пиджина»), возникающего и используемого в процессе коммуникации между торговцами и покупателями. Географически отдаленные друг от друга и находящиеся в совершенно разных непосредственных контекстах, обе площадки можно рассматривать как приграничные. Кроме того, на обоих рынках торговцами обычно являются этнические китайцы, говорящие на китайском языке (путунхуа), а клиенты преимущественно русскоязычные, что вызывает необходимость в языковых услугах. Фактически рынок в Пекине имеет давнюю репутацию коммуникативного пространства, дружественного русскому языку, что созвучно описанию дискурсивных практик Н. Сурьянараян на рынке Дели, обслуживающем русскоязычных покупателей и туристов из стран постсоветского пространства (Suryanarayan 2017).

В этом отношении данные исследовательские объекты исторически рассматриваются как этнические пространства языковых контактов, и поэтому авторы также демонстрируют отношение к российско-китайским контактным языкам, а также их потенциальную, хотя и довольно ограниченную рыночную стоимость. Кроме того, статья Григоричева и Гузей показывает, что появление и, по-видимому, 
постоянное развитие контактных языков на этих рынках должно рассматриваться в связи с конкретным контекстом китайско-российской границы. Хотя они не находятся непосредственно на границе, в определенной степени они напоминают коммутативные практики, характерные для приграничных территорий.

М. Еленевская и Л. Фиалкова ставят своей целью изучение использования русского языка в Израиле. В своей статье под названием «Языковой ландшафт: что он нам говорит об интеграции русского языка в экономику Израиля» авторы применяют многосторонний подход к изучению языка в публичной сфере, уделяя особое внимание роли русскоговорящих иммигрантов из стран постсоветского пространства. Для своего анализа авторы используют три метода сбора данных и соотносят их друг с другом, начиная от (1) языкового ландшафта, (2) анализа русскоязычных израильских веб-сайтов до (3) этнографических полевых заметок, сделанных во время наблюдения и интервью. Все методы дополняют друг друга, но в основе анализа авторов лежит исследование взаимоотношений между русскими надписями, а также веб-страницами и мотивацией заинтересованных сторон, принимающих решения о том, где и в каких ситуациях уместно и выгодно использовать русский язык.

В статье анализируется использование русского языка в тех сферах государственного и коммерческого секторов, которые требуют интенсивного использования языка. Особое внимание авторы уделяют использованию культурных символов в качестве маркетинговой стратегии.

С таким же акцентом на языковой ландшафт, но с более явной исторической перспективой, М. Ольнова в своей работе «Русский язык в Северной Норвегии: исторические, культурные и экономические связи» снова обращается к понятию приграничья, описывая языковую ситуацию в Киркенесе, городе в Северной Норвегии. В последние годы Киркенес стал популярным местом для шоппинг-туристов из Мурманской области. В статье рассматривается процесс коммодификации русского языка в Киркенесе и его связь с появлением новой экономики и современной политикой сотрудничества между Норвегией и Россией. Автор прослеживает попытки местных властей возродить историческую «поморскую торговлю» и опирается на лингвистическое исследование, основанное: (1) на анализе корпуса, состоящего из 100 изображений витрин, дорожных знаков и изображений интерьеров магазинов; (2) на анализе печатных материалов и официальных документов для русскоязычных туристов, а также (3) на материалах интервью с российскими туристами и представителями местного населения. Ситуация в Киркенесе иллюстрирует трансформацию «старой экономики» в новую, которая характеризуется структурными экономическими изменениями и ростом экономики услуг. Бывший горнодобывающий город трансформировался в туристический центр, где русскоязычные посетители могут рассчитывать на обслуживание на русском языке. Киркенес становится одним из центров российско-норвежского сотрудничества и трансграничного обмена. Ситуация с русским языком в городе сразу же бросается в глаза на фоне местного языкового ландшафта.

М. Кабал-Гуарро в статье «Экономическая значимость русского языка в Каталонии: вектор роста или падения» ставит вопрос о коммодификации и возмож- 
ной декоммодификации русского языка в Каталонии, регионе Испании, который, благодаря своей природной красоте, достопримечательностям и приморским курортам, приобрел большую популярность среди туристов из России и стран бывшего Советского Союза. Автор исследует примеры коммодификации русского языка в каталонской индустрии туризма посредством стандартизированных интервью с владельцами магазинов, анкет для русскоговорящих работников службы сервиса, а также данные о языковом ландшафте городов Барселоны и Салоу и сравнивает свои результаты со статистическими данными о туристских потоках из России. Целью этого исследования является отслеживание значимости русского языка с течением времени и на фоне колебания числа русскоязычных туристов. В этом контексте анализ М. Кабал-Гуарро будет способствовать лучшему пониманию того, как развивается языковая коммодификация и (возможно) декоммодификация и как политика и экономика влияют на валоризацию определенных языков. Автор обращает особое внимание на необходимость рассмотрения взаимосвязанности процессов коммодификации языка с глобальной экономикой и (гео)политическими событиями.

Две последние публикации данного выпуска касаются вопросов, которые непосредственно не рассматриваются в других статьях номера.

Х. Виймарант, Е. Протасова и А. Мустайоки в своей статье «Коммодификация русского языка в Финляндии» прослеживают историю русского языка в этой стране, делая тонкие наблюдения над использованием русского языка в современном финском обществе. Авторы отмечают попытки коммодифицировать русский язык в сфере обслуживания русскоязычных туристов, посещающих страну, и приводят факты, демонстрирующие, какие деловые перспективы открываются для россиян, проживающих в настоящее время в Финляндии. Они утверждают, что в последние годы знание русского языка стало значительным преимуществом на местном рынке занятости как для русскоязычных иммигрантов, так и для относительно небольшого числа финнов, которые могут говорить по-русски. Эта ситуация нашла свое отражение в значительном спросе среди русскоязычных родителей в Финляндии на образовательные услуги для своих детей в дополнение к школьному образованию на финском языке.

А. Пенчева в своей статье «РЕТУР — инновационный ресурс для обучения русскому языку работников туризма в странах ЕС» обсуждает преимущества программы самостоятельного изучения русского языка для сферы услуг в Европейском Союзе. Разработанная как онлайн-программа и инструмент обучения, РЕТУР предлагает возможность приобрести навыки русского языка, необходимые для индустрии туризма. А. Пенчева приходит к выводу, что туристическая отрасль экономики ряда стран Европейского Союза заинтересована в обучении русскому языку сотрудников в сфере туризма для того, чтобы развивать свои коммуникативные ресурсы и расширять туристическую отрасль в направлении русскоязычных рынков.

Данные работы могут вызвать вопрос — что дают нам исследования коммодификации русского языка и каковы их дальнейшие перспективы? Как напоминает 
нам А. Павленко в статье этого спецвыпуска, наблюдаемая в последнее время коммодификация русского языка дает нам возможность изучать язык в новых социальных и географических условиях и проанализировать, как изменился статус и функции русского языка после распада Советского Союза. В то же время она показывает, как коммодификация пересекается с глобальным ростом неолиберальной экономики, расширением рыночной логики во всех областях общественной жизни и особой экономической, исторической и культурной ролью России в посткоммунистическом миропорядке. Все это позволяет нам изучать значение русского языка в транснациональной сфере обслуживания и констатировать, что русский язык, наряду с английским и китайским, стал востребованным товаром. В настоящее время русский язык можно считать одним из самых популярных и широко используемых языков в сфере транснациональных услуг, включающих традиционный туризм, медицинский туризм, транспорт, недвижимость и маркетинг (Арефьев 2017, Павленко, этот выпуск). Мотивы инвестирования в русский язык, которые могут быть либо индивидуальными (например, изучение языка), либо как выражение корпоративной или государственной политики (например, целенаправленный наем работников, владеющих русским языком), во многом связаны с экономическими мотивами, подпитываемыми прогнозами туристических потоков. Здесь инвестиции в русский язык могут обеспечить добавочную стоимость услугам, предлагаемым на этом языке. Все это показывает, как и по каким причинам русский язык приобрел ценность в более широких социальных, экономических и политических контекстах. Как будет показано в предлагаемом вашему вниманию специальном выпуске, обстоятельства и последствия коммодификации русского языка тесно связаны с глобализацией, растущей мобильностью русскоязычных, а также глобальной сервисной индустрией, которая продолжает расширяться на новых рынках.

Однако, как подчеркивает А. Павленко в этом специальном выпуске, исследование данного явления требует четкого понимания соответствующих методов и эмпирически-ориентированных подходов, которые рассматривают язык в его непосредственном социальном контексте. Аналогичным образом оно требует хорошо сформулированных методов выборки данных, которые являются прозрачными и воспроизводимыми. Социолингвистические исследования, посвященные использованию русского языка за рубежом и, в частности, коммодификации русского языка, предлагают ученым беспрецедентные возможности для изучения процесса превращения языка в ценный коммуникативный ресурс.

(C) Sebastian Muth, 2017

\section{СПИСОК ЛИТЕРАТУРЫ / REFERENCES}

Anderson, B. (1991) Imagined communities. London: Verso.

Арефьев, А. Современное состояние и тенденции распространения русского языка в мире. Москва: Институт социально-политических исследований РАН, 2017. [Aref'ev, А. (2017) Sovremennoe Sostoyanie i Tendentsii Rasprostraneniya Russkogo Yazyka v Mire. (Current Sta- 
tus and Trends of the Russian Language Expansion worldwide). Moscow: Institut sotsial'nopoliticheskikh issledovanii RAN (In Russ).]

Baločkaite, R. (2014) On Ideology, Language, and Identity: Language Politics in the Soviet and PostSoviet Lithuania. Language Policy 13, 1: 41-61.

Brennan, S. C. (2017) Advocating commodification: an ethnographic look at the policing of Irish as a commercial asset. In S. Muth and A. Del Percio (eds.) Policing languages and speakers for commodification, Special issue, Language Policy, 1-21. doi: 10.1007/s10993-017-9438-2.

Boutet, J. (2008) La vie verbale au travail. Des manufactures aux centres d'appels. Toulouse: Octares.

Cameron, D. (2001) Good to Talk? London: Sage.

Cameron, D. (2012) The commodification of language: English as a global commodity. In T. Nevalainen and E. C. Traugott (eds.) The Oxford handbook of the history of English, 352-361. Oxford: Oxford University Press.

Cavanaugh, J. and Shankar, S. (2014) Producing authenticity in global capitalism: Language, materiality, and value. American Anthropologist 166, 1: 51-64.

Connell, J. (2016) Reducing the scale? From global images to border crossings in medical tourism. Global Networks 16, 4: 531-550.

Coupland, N. and Garret, P. (2010) Linguistic landscapes, discursive frames and metacultural performance: The case of Welsh Patagonia. International Journal of the Sociology of Language, 205: 7-36.

Del Percio, A. (2016) Branding the Nation: Swiss Multilingualism and the Promotional Capitalization on National History under Late Capitalism. Pragmatics and Society 7, 1: 82-103.

Duchêne, A. (2009) Marketing, management and performance: Multilingualism as commodity in a tourism call centre. Language Policy 8, 27-50.

Duchêne, A. (2011) Néolibéralisme, inégalités sociales et plurilinguismes: l'exploitation des ressources langagières et des locuteurs. Langage et Société, 136: 81-106.

Duchêne, A. and Flubacher, M. (2015) Quand légitimité rime avec productivité: La parole-d'œuvre plurilingue dans l'industrie de la communication. Anthropologie et Sociétés 39, 3: 173-196.

Gal, S. (1989) Language and political economy. Annual Review of Anthropology 18: 345-367.

Grumadienè, L. (2005) Language Policy and the Sociolinguistic Situation in Lithuania. Mercator Working Papers 19.

Heller, M. (2003) Globalization, the New Economy, and the Commodification of Language and Identity. Journal of Sociolinguistics 7, 4: 473-492.

Heller, M. (2010) The Commodification of Language. Annual Review of Anthropology 39: 101-114.

Heller, M. and Duchêne, A. (2012) Pride and Profit: Changing Discourses of Language, Capital, and Nation-state. In A. Duchêne and M. Heller (eds.) Language in Late Capitalism: Pride and Profit, 1-21. New York: Routledge.

Heller, M., Pujolar, J. and Duchêne, A. (2014) Linguistic commodification in tourism. Journal of Sociolinguistics 18, 4: 539-566.

Heller, M. and Duchêne, A. (2016) Treating language as an economic resource: Discourse, data, debates. In N. Coupland (ed.) Sociolinguistics: Theoretical debates, 139-156. Cambridge: Cambridge University Press.

Holborow, M. (2007) Language, ideology and neoliberalism. Journal of Language and Politics, 6, $51-73$.

Holborow, M. (2015) Language and neoliberalism. London: Routledge. 
Irvine, J. (1989) When talk isn't cheap: Language and political economy. American Ethnologist 16(2), $248-267$.

Kelly-Holmes, H. (2005) Advertising as multilingual communication. Basingstoke: Palgrave MacMillan.

Marcus, G. (1995) Ethnography in/of the World System: The Emergence of Multi-sited Ethnography. Annual Review of Anthropology 24, 95-117.

Muth, S. (2017a) Russian as a commodity: medical tourism and the healthcare industry in post-Soviet Lithuania, in Muth, S. and L. Ryazanova-Clarke (eds.) The commodification of Russian, Special issue, International Journal of Bilingual Education and Bilingualism 20(4): 404-416.

Muth, S. (2017b) 'The ideal Russian speaker is no Russian': Language commodification and its limits in medical tourism to Switzerland. In S. Muth and A. Del Percio (eds.) Policing languages and speakers for commodification, Special issue, Language Policy, $1-21$. doi: 10.1007/s10993-017-9434-6.

Park, J. (2016). Language as pure potential. Journal of Multilingual and Multicultural Development 37, 5: $453-466$.

Pavlenko, A., (ed.) (2008) Multilingualism in Post-Soviet Countries. Bristol: Multilingual Matters.

Pavlenko, A. (2010) Linguistic landscape of Kyiv, Ukraine: A diachronic study. In E. Ben-Rafael, E. Shohamy and M. Barni (eds.) Linguistic Landscape in the City. Clevedon: Multilingual Matters, 133-152.

Pavlenko, A. (2017) Russian-friendly: how Russian became a commodity in Europe and beyond. In S. Muth \& L. Ryazanova-Clarke (eds.) The commodification of Russian around the world (Special issue). International Journal of Bilingual Education and Bilingualism, 20(4): 385- 403.

Piller, I. and Cho, J. (2013). Neoliberalism as language policy. Language in Society, 42(1): 23 - 44.

Ponton, D., Larina, T. (2017) Discourse Analysis in the 21st Century: Theory and Practice (II). Russian Journal of Linguistics, 21 (1), 7-21.

Sharma, B. K. and Phyak, P. (2017) Neoliberalism, linguistic commodification, and ethnolinguistic identity in multilingual Nepal. Language in Society, 46: 231-256.

Smith, D. (2005) Institutional ethnography: A sociology for people. Oxford: AltaMira Press.

Suryanarayan, N. (2017) From Yashwant Place to Yashka: a case study of commodification of Russian in India. In S. Muth and L. Ryazanova-Clarke (eds.) The commodification of Russian around the world (Special issue). International Journal of Bilingual Education and Bilingualism, 20(4): $428-442$.

Tan, P. K. W. and Rubdy, R. (eds.) (2008) Language as commodity: Global structures: Local marketplaces. London: Continuum.

Uffelmann, D. (2013). Post-Russian Eurasia and the proto-Eurasian usage of the Runet in Kazakhstan: A plea for a cyberlinguistic turn in area studies. Journal of Eurasian Studies, 2, 2: 172-183.

Urciouli, B. and LaDousa, C. (2013) Language management/labor. Annual Review of Anthropology, 42: $175-190$.

Urry, J. (2007) Mobilities. Cambridge: Polity Press.

\section{For citation:}

Muth, S. (2017). Russian Language Abroad: Viewing Language through the Lens of Commodification. Russian Journal of Linguistics, 21 (3), 463-492. doi 10.22363/2312-9182-2017-21-2-463-492.

Для цитирования:

Muth, S. (2017). Русский язык за рубежом: взгляд на язык сквозь призму коммодификации // Вестник Российского университета дружбы народов. Серия: Лингвистика. 2017. T. 21. № 3. C. 463-492. doi 10.22363/2312-9182-2017-21-2-463-492. 


\section{Bio Note:}

Dr. Sebastian Muth, Senior researcher, Institute of Multilingualism, University of Fribourg. Research interests: Sociolinguistics, commodification of languages. Contact information: e-mail: sebastian.muth@unifr.ch

\section{Сведения об авторах:}

Доктор Себастьян Мут, старший научный сотрудник, Институт многоязычия, Университет Фрибурга. Сфера научных интересов: социолингвистика, коммодификация языков. Контактная информация: e-mail: sebastian.muth@unifr.ch 